\title{
THE EXISTENCE OF COLLATERAL IN CREDIT THROUGH PEER-TO-PEER LENDING SERVICES
}

\author{
Ninis Nugraheni'; Qonitah Annur Aziza² \\ ${ }^{1}$ Faculty of Law, Universitas Hang Tuah; ${ }^{2}$ Faculty of Law, Universitas Airlangga \\ Email: ninis.nugraheni@hangtuah.ac.id; qonita0306@gmail.com
}

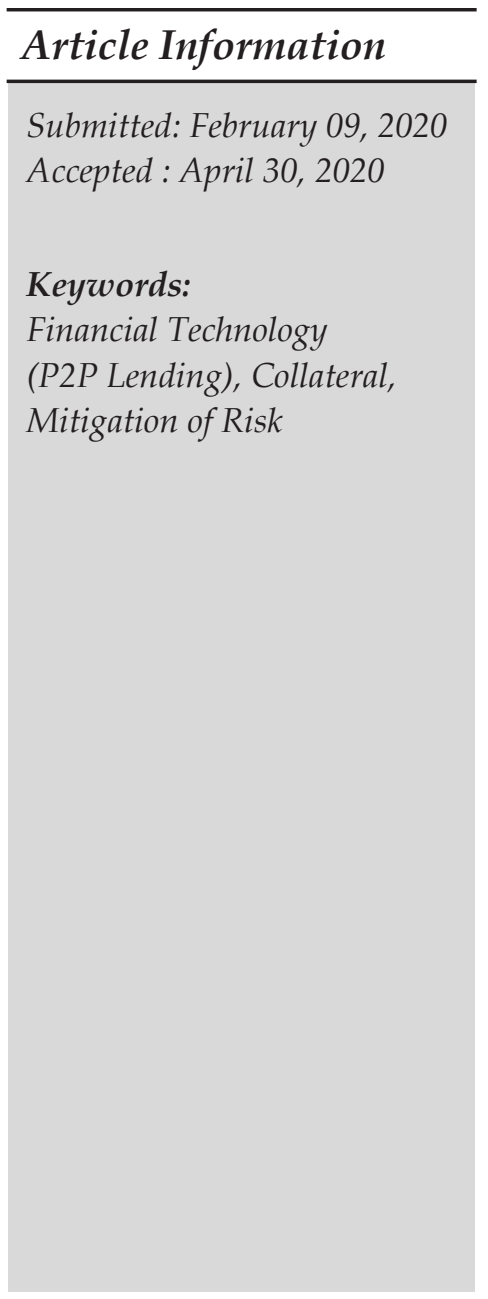

\begin{abstract}
Recently, the total number of registered P2P Lending Fintech promoters has reached 144 companies after 17 fintech joined in one month and had a business license in October 2019. The status of business lisence conferred to platforms registered in OJK has met a number of requirements such as information security in the form of ISO 271001, digital signature and the principle of risk management. As an "umbrella organizationn" for all fintech companies in Indonesia, Indonesia Fintech Association (i.e., AFTECH) has 280 members, which 250 of them operate their business in digital financing system, online credit, innovation on digital finance, insuretech, equity crowdfunding, and etc. The rapid growth of the fintech industry may definitely make a huge contribution to the Indonesian people, especially for retail and unbanked segments. However, this rapid growth potentially evokes legal problems on its implementation as the implementation of credit on peer-to-peer lending does not bring the engaged parties into person but solely through online-access in addition to its less prudence of making transactions, a default of loans which injures the creditors may likely to happen. The importance of legal protection for creditors by selecting an appropriate mitigation of risks (e.g., fiduciary warrant) as a legal assurance for engaged parties, especially the preferent creditors in terms of possessing the fiduciary certificate when it comes to default. The result of this study with the fiduciary agreement, it will be prioritized in credit disbursement when the debtor turns into bangkruptcy and thus they are not allowed to use their loans for another purpose
\end{abstract}

\section{Introduction}

Financial Technology Peer to Peer Lending (hereinafter referred to P2P Lending) becomes an umbrella of investment and financial credit for the public. The regulation of financial service authority (POJK) Number 77 of 2016 has mentioned that P2P lending is an organization of financial services that brings lender and borrower together to make direct credit transactions in rupiahs electronically through the internet.

As a department that organizes regulation and supervision systems in the financial services sector, OJK has roles in the development of P2P Lending. It has issued a regulation on financial technology, namely the Financial Services Authority Regulation Number 77 / POJK.01 / 2016 concerning Technology-Based Money Lending and 
Borrowing Services (POJK Number77 / POJK.01 / 2016). The regulation becomes the basis for the implementation of unsecured loan business activitiesa which are usually known as P2P Lending. This regulation also regulates OJK's supervision of the running of these business activities. The implementation of P2P Lending financial technology in POJK above is classified as other financial service institutions that fall within the realm of supervision of the Non-Bank financial industry sector. Like other financial services institutions, the implementation of P2P Lending financial technology must be overseen by the OJK as an authority that has the authority to conduct microprudential supervision in Indonesia.

Financial technology services, in particular to unsecured loans, have advantages in providing convenience and benefits to the community, because both lender and borrower are no longer need to meet in person. They are only brought together through a website or application with very practical $T \& C$ and the process is very quick rather than conventionally borrowing money through a Bank Institution. In addition, it also has a limitation as it actually weakens the creditor's position. Neither lender nor borrower has the chance to meet each other in person since the transaction uses the website or online application provided by the financial service provider. Hence, fraudulence by the borrower is likely to happen and it may injure the lender.

Magee (2011) argued that the primary advantage of P2P Lending for borrowers was having credit with lower collateral, while the lender might gain a higher return of their investment. On the other hand, Haewon et al. (2012) and Giudici (2018) explained that there was no investment without risk, including investing in P2P Lending. Unlike in the banking system, it entirely belongs to the lender (no the P2P Lending company) when credit gets troubled. Pokorna and Sponer (2016) argued that the biggest risk that belongs to the lender refers to bad credit (i.e., default) by the borrower.

Fintech has currently had many functions in addition to online financial transaction services. The result of research by Indonesia Fintech Association suggested that nowadays, fintech companies in Indonesia are still dominated by payment companies $(44 \%)$, aggregators $(15 \%)$, finances $(15 \%)$ financial planner for personal and companies $(10 \%)$ crowdfunding $(8 \%)$. Furthermore, two fintech platforms which recently catch big attention from public are P2P Lending (P2P L) and Payment gateway. Those two platforms are connected with big econsystem of fintect and are the most favorable financial services as a solution against disparities of financial inclusion on banking products.

The more it develops, the more potential borrowers of P2P Lending prefer to go with online companies rather than the conventional ones. As described in the previous paragraph, P2P Lending service is an alternative of investment and financing sources with a very practical process for the public. Having investment in the P2P Lending sector promises to return for the lender. The more people interested in this service, the more risks may happen such as payment issues by borrowers. One potential risk likely to happen is a breach of contract of default by the borrower. Therefore, it needs a legal assurance for a lender such as a fiduciary guarantee as collateral to avoid any potential risks. 
Considering the importance of credits issues In development process, it is duly to give protection to the recipients and contributor that able to give legal certainty for any related parties (general explanation point 1 of The Mortgage Law). The existence of goods guarantee, like mortgage, is an implementation of the precautionary principle which is mandated by the Banking Act. Mandate of the Act is given as the banks are just intermediaries who bridge the flow of capital / investment of the investors and the public at large to the businesses and people that need capital (Moch Najib Imanullah, 2018:187). The presence of material security is one element of both preventive and curative protection for the creditor due to the material security with economy value, and it can be shifted to give convenience for the creditors to execute the collateral object. For credit settlement in case that the debtor is default (Herowati Poesoko: 2008) (Trisadini Prasastinah Usanti., et al, 2019:163).

The definition of warrant itself is a creditor-debtor agreement through which the debtor assures particular amount of his assets for credit settlement under a set of applied laws in case of bad credit by the debtor (Gatot Supramono, 2009: 75). The warrant refers to the debtor's assets pledged to the creditor in case that the debtor fails to repay his loan. It is one component financing analysis.

Looking into several warrants applied in Indonesia such as mortgage, pawning, collateral right, fiduciaty, and warehouse receipt, it is more appropriate to use fiduciary. An advantage of applying fiduciary is that this kind of warrant will not be nullified in case of the debtor's bankruptcy (Article 27 subsection (3) Act Number 42 year 1999 about Fiduciary Warrant). With this lex, an agreement using fiduciary warrant seems is indeed effective for giving legal protection to the creditors, as they have preferent position.

The juridical function of fiduciary in fiduciary deed defines the position of creditor as preferent creditors. They may have a legal assurance of credit repayment by the debtors. In addition, this juridical function allows banks and fintech companies to mitigate any possible risks of loss in running their business. Fiduciary is manifested in the form of "taking over a trustworthy-based proprietary right" or commonly called Fiduciare Eigendoms Overdarcht. Lexes do not see the possession of fiduciary as the creditor's absolute possession over the warrant. Otherwise, it is recognized as a restricted proprietary right that aims only for collateral (Riedel Wawointana, 2013: 108).

POJK 77 year 2016 mentions that P2P Lending Fintech companies are not allowed to become creditors, but solely as mediators/agent. Unlike banks which role is indeed as creditors, bot creditor and debtor may meet in person to apply a fiduciary warrant and register the collateral object into fiduciary registration office for the sake of legality for both parties. Based on Government Regulation Number 21 Year 2015 about Registration Procedures and Deed Establishment Cost of Fiduciary Warrant, however, online registration may currently be applied. Therefore, the engaged parties do not need to meet in person anymore.

According to introduction section, this article analyzes the importance of collateral as risk mitigation and legal protection for engaged parties. In this case, fiduciary is applied as the manifestation of prudence or circumspection in peer-to-peer lending services. 


\section{Research Methods}

This study is normative-juridical research that focuses on examining the application of rules or norms in positive law. Legal research investigating literature materials may refer to a normative law study or legal research on topic-related literature area.

Both statute and conceptual approaches are used. The former is carried out to examine all of the rules and regulations related to the topic of discussion. The later is carried out to examine the concepts of perspectives and doctrines in legal science.

This study uses descriptive analysis for data analysis. It focuses on the research questions to be addressed by collecting any existing legal sources to be analyzed and identified through library research by describing each of the problems befor selecting the appropriate ones.

\section{Research Result and Discussion}

\section{A. Characteristics of Credit through Peer to Peer Lending Service}

Credit is a measure of a person's capability to get something with economic value as the exchange of his promise to pay back his loan in a particular time/ date (Darman, 2019:131). One type of fintech that could play a key role in the near future are the so-called neo-banks or challenger banks (Pranoto, P., Kholil, M., \& Tejomurti, K. 2019: 105). The fintech companies are taking advantage of these two factors - internet penetration and technological development - in order to lead the transformation of the financial sector, offering more efficient processes, new models for obtaining credits and mobile applications that benefit individuals, SMEs and even the traditional financial entities themselves (Priskarini, I. A., \& Tejomurti, K. 2019: 556). These mobile-only banks only offer an account and a debit or credit card as their own products. All other products are offered through partnerships with other fintechs or daily-use companiesIt brings such a cooperative advantage between creditors and debtors. They take benefits to one another, as well as the risks. An unsecured loan through P2P Lending is a practice of providing credit to individuals with neither directly meeting in person nor through an intermediary bank. Such a credit transaction occurs online through Fintech Company's website.

$\mathrm{P} 2 \mathrm{P}$ lending is a lending-and-borrowing transaction based on crowdfunding. In this case, lenders are offered a certain level of profit for a project if the project is paid (Paul Belleflamme et, al, 2015:1). The mechanism of P2P lending is as follows:

1) At the first stage, both lender and borrower must create an account on a platform that provides a marketplace lending. In order to create this account, they are required to agree to the $T \& C$ of using marketplace lending.

2) The borrower requests a loan of funds to a P2P lending company.

3) The requests for loans received by P2P lending companies will be selected and appraised at the risk level by the company.

4) After being selected, the loan application that passes will be displayed and 
arranged according to the level of risk in the marketplace lending, which in this case is the World Wide Web.

5) Lenders can directly choose which lending marketplace loan applications to fund. In order to fund, the lender must first make a deposit to the account that he has at the P2P lending company.

6) After making a deposit and choosing which loan application to funding, a P2P lending agreement will be formed between the lender, the loan recipient, and the $\mathrm{P} 2 \mathrm{P}$ lending company as an intermediary that will channel the funds.

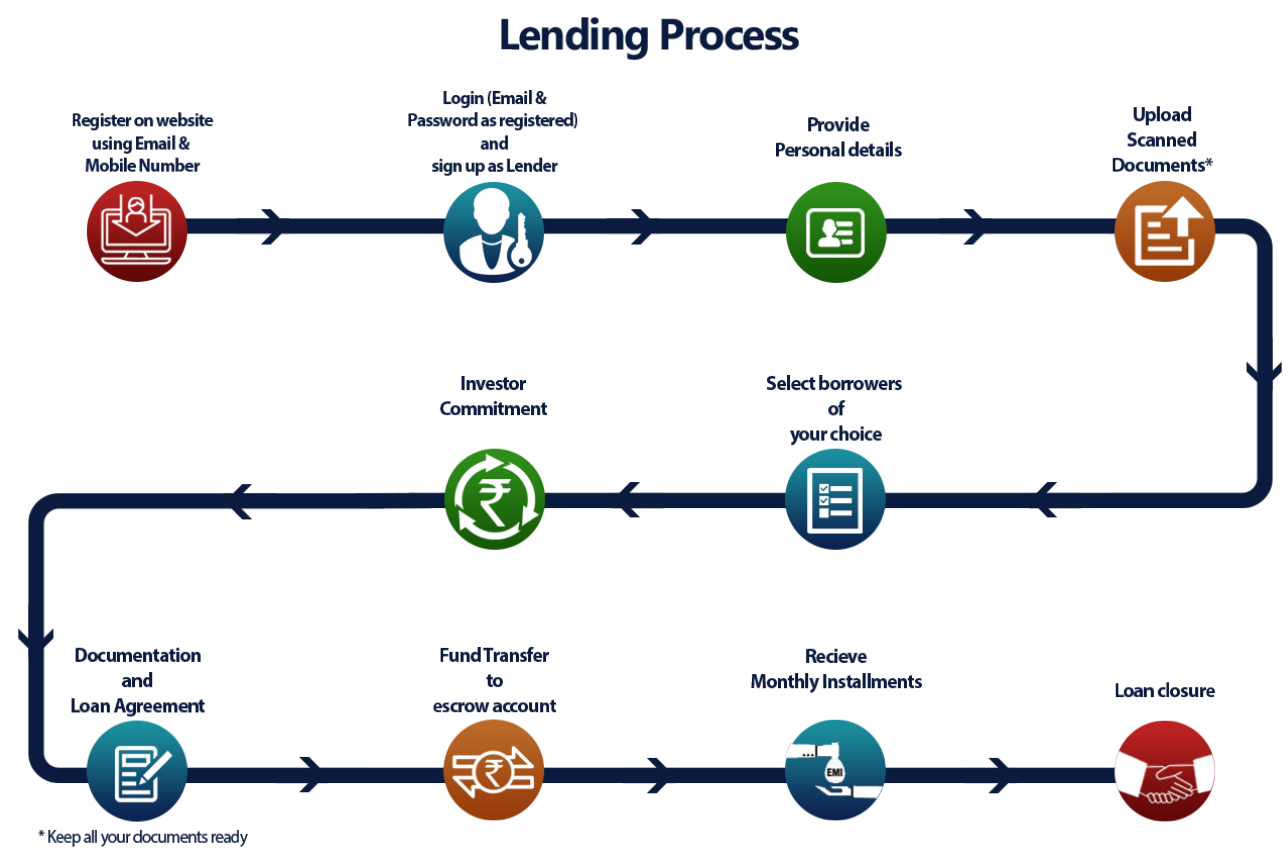

Source: OJK Consumer Protection Department

Explanation:

1) Consumers use the platform and sign up as lender or borrower

2) Both lender and borrower fill out the registration form and submit any required documents

3) The lender will have an account and may find borrowers who want to be funded through the platform

4) The company will assess their credit applications and bring the lenders and borrower together via its platform using a crowdfunding process

5) If the fund are all collected, it will be disbursed and the borrower starts to have an installment payment obligation

6) In case that the installment is well paid, the funder may gain their return. In case the payment is overdue, the procedures of internal credit collection will be carried out with assistance from the service provider company. In case it comes to default, the company will assist the loan repayment process. In addition, in case that it remains failed, legal action is the last option and the funder is likely to bear the risk of loss. 
In running their business, $\mathrm{P} 2 \mathrm{P}$ lending service provider companies may gain profit from the fee of approved credit in addition to service fees in either fixed or percentage-based amount. The characteristics of credit through this service are as follow:

1) The concept of credit through financial technology services is slightly similar to conventional banks but where the transaction takes place, given that fintech lending service is through online

2) There is no previous bond or relationship between the lender and the borrower

3) Both offer and approval are through an online system

4) The service provider plays as an intermediay party

5) The lender may choose which prospective borrowers to be invested

6) Unsecured loans

7) Loans can be in the form of securities that can be sold to other lenders.

\section{Chart of Credit in P2P Lending}

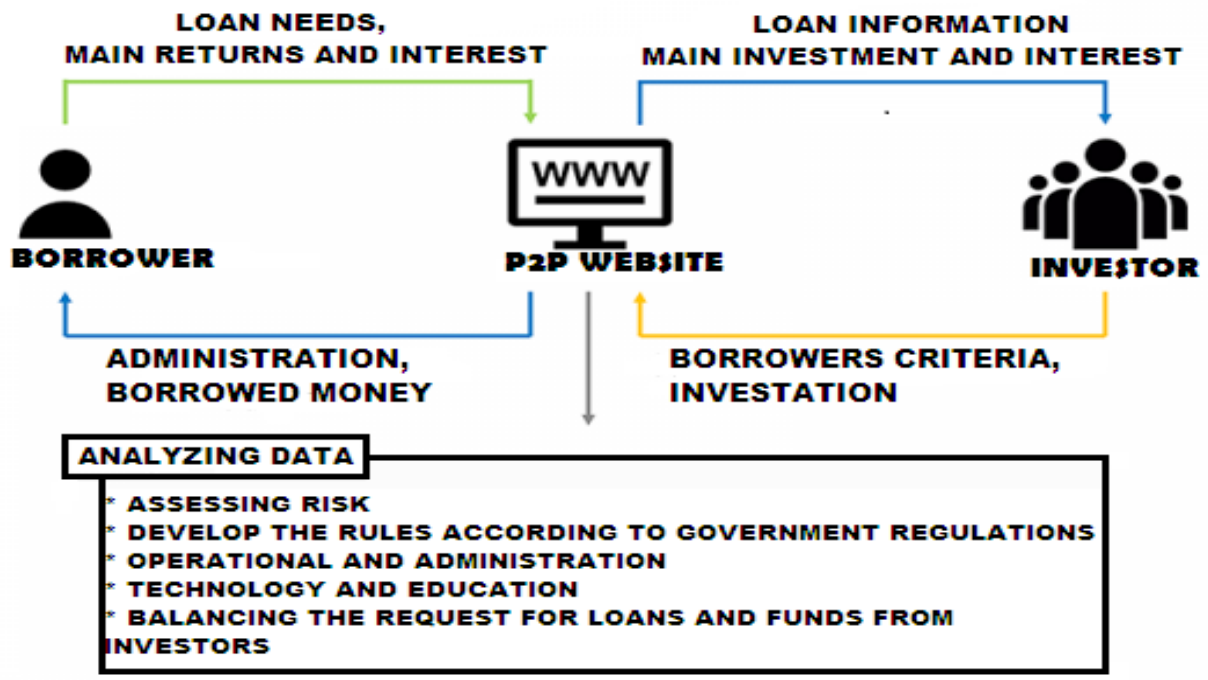

Source: Alficha Rezita Sari (Alficha Rezita Sari, 2018:73).

Toward credit agreement through P2P lending, Article 18 POJK Number77/ POJK.01/2016 mentions that the agreement of technology-based credit services involves a service provider-lender contract, lender-borrower contract. Based on Article 1 subsection (6) POJK Number77 / POJK.01 / 2016, the service provider of $\mathrm{P} 2 \mathrm{P}$ lending who is considered as the administrator is Indonesia legal entity that provides, manages, and operates technology-based credit service. The administrator is defined as Other Corporate Financial Service Provider in the form of either incorporated company or joint venture. The administrator acts as an intermediary that provides software-based service using a website or platform to bring both lender and borrower together for a transaction. 
Based on Article 1 subsection (7) POJK Number77/ POJK.01/2016, the credit recipient is an individual and/or legal entity with debts due to Information Technology-based credit agreements. Furthermore, Article 15 POJK Number77/ POJK.01.2016 mentions that it is a must for the credit recipient to come from and domicile in Indonesia jurisdiction, either an individual or legal entity. In addition, Article 1 subsection (8) POJK Number77POJK.01/2016 mentions that lenders are individuals, legal entities and/or business entities with accounts receivable due to technology-based credit agreements. They are either domestic or foreign parties. They provide credit or funds to loan recipients in needs through a platform.

A fintech lending administrator merely provides a marketplace for both lender and borrower to make an online fintech-lending-based credit transaction via the administrator's platform. The administrator is not engaged in the lender-borrower agreement, but solely as an authorized party on behalf of the lender to distribute their fund to the borrower in the form of credit/loans. The administrator has neither responsibility nor obligation in any fintech-lendingbased credit agreement, and thus, the agreement is solely between the lender and borrower.

Based Act Number 19 year 2016 about the Amendment of Act Number 11 year 2008 about Elctronic Transaction and Information (later called UU 11/2008), the utilization of information technology and the electronic-based transaction is based on some principles including legal assurance, benefits, prudence, good will, and freedom to choose either using technology or neutral. Maskun has described those all principles in more detail as follow. ${ }^{5}$

1) Legal Assurance

It refers to a legal base for the users of information technology and electronic transaction as well as anything that supports the implementation of legal recognition inside and outside the court.

2) Benefits

It defines that the principle of using information technology and electronic transactions are intended to support the process of informing for the sake of people's prosperity.

3) Prudence

It defines that the engaged parties should take into account every aspect that may evoke loss, both for themselves and the others, in the process of using information technology and electronic transaction.

4) Goodwill

It defines that the engaged parties in the electronic transactions have no intention to do a crime that may injure another party.

5) Freedom to either Use Technology or being Neutral

It defines that the utilization of information technology and the electronic transaction is not merely about using a particular technology. Otherwise, it may go along with future development. 
Wahyu Anggoro argues that, apart form those five principles, there are also some principles from BW, as follows (Wahyu Hanggoro Suseno, 2008:45).

1) Freedom to Make Contract

2) Consensualism

3) Goodwill

4) Trust

5) Pacta Sunt Sevanda

An electronic agreement, in particular to P2P Lending, has a confining legal power for all the engaged parties as what other agreements are commonly made. Article 18 subsection (1) of Act 11/2008 mentions that "electronic transaction as mentioned in electronic contract confines the engaged parties." it implies that the P2P Lending contract is similar to another agreement commonly made based on Article 1320 BW.

P2P lending contract creates a legal relationship that derives from a contractual relationship between the engaged parties including the lender, borrower, and the administrator of $\mathrm{P} 2 \mathrm{P}$ lending. The legal relationship in P2P Lending is set under Article 18 POJK 77/2016, and it involves:

1) An agreement between the administrator and the lender;

2) An agreement between the lender and the borrower.

In accordance with those all mechanisms, there is a legal relationship between the lender and the administrator of P2P Lending. As previously discussed, an administrator-lender agreement is a kind of giving authorization to an exclusive authority. Thus, the administrator may manage the lender's fund to be distributed to any qualified borrowers in the form of loans/credit based on their selection and analysis process. Based on Article 1792 BW, the agreement of authorization gets a party to authorize another party to organize an affair on behalf of his name. The authority is in the form of either official deed, unofficial letter (written) or verbally mentioned.

Given that P2P Lending agreement put the lender into a high-risk concurrent creditor who may lose their fund entirely/partly due to debtor's default, it is important to make an assessor agreement in the form of fiduciary agreement based on Article 5 of Act 42/1999 of primary agreement (i.e., P2P lending). It aims to shift the status of a lender from concurrent creditor to preferent one due to that fiduciary agreement in order to get privilege (droit de preference).

In addition to such power of attorney, another function turns up due to fiduciary agreement. Hsowever, the authority is now coming from the borrower to the P2P lending service administrator/provider. It is an authority shift from the borrower/fiduciary giver to the P2P lending service administrator in order to see a notary for making a fiduciary agreement. It happens when both lender and borrower are unable to see the notary for making their fiduciary agreement. After establishing a fiduciary agreement, the imposition of fiduciary guarantee must be registered by the lender, as set under Article 21 subsection (1) of OJK 
Regulation Number 29/POJK.05/2014 about Financial Service Administrator (later called POJK 29/2014): "Financial companies that require a fiduciary guarantee in providing finance should register the intended guarantee to the fiduciary registration office, as set under the law of fiduciary guarantee."

The credit guarantee is one fundamental aspect of providing credit. The function is to secure the credit: nullifying or, at least, mitigating any possible risks that must be charged to the creditor, on which the debtor is default or breaking his promise. Therefore, it is important to have collateral to avoid any risks. A fiduciary guarantee is dependent on its primary agreement that evokes obligations among the engaged parties in order to complete their performance which can be valued by money although the primary agreement is made either authentically or unofficially (A.A. Andi Prajitno, 2009:204). As the consequence of the assesor agreement, the fiduciary agreement may be nullified or over if the primary agreement is invalid or lost due to whatever cause.

Toward the position and legal assurance for the engaged parties, Article 18 subsection (1) of Act 11/2008 mentions that electronic transactions set in electronic agreement confine all the engaged parties. Similarly, the principle of Pacta Sunt Servanda in Article 1338 subsection (1) BW mentions that all of the agreements made based on the law will apply as regulations for those who make the agreement. Broadly speaking, the P2P lending agreement is similar to the other agreements commonly contained in BW. In this case, however, it uses the internet which does not require the engaged parties to meet in person for having a contractual relationship called the P2P lending agreement.

The agreement is made and implemented based on applied law and consent among the engaged parties. P2P lending agreement is also a sign that they are engaged to one another in a legal relationship which results in rights and obligations among those parties. a contractual relationship results in rights and obligations that must be completed. Generally, it is a must for the lender to provide funds as much as what has been mentioned in the agreement. This obligation evokes a right that the borrower must pay back his loan along with the interest they have agreed to.

Neither right nor obligation among the engaged parties is set under POJK that regulates P2P lending but based on their consent. Those rights and obligations give the symbol of legal position among the engaged parties, as well as the fiduciary agreement which refers to the assessor agreement from the P2P lending agreement. The agreement is made since the engaged parties are willing to do financing and loans. They agree to be engaged in a legal relationship.

\section{B. Prudence in Credit Agreement through Peer to Peer Lending}

A collateral agreement is made due to a primary agreement. It is a kind of assessor agreement; which adheres to the primary agreement. Hence, it is called a tail agreement as it is dependent (Etty Mulyati, et al, Bandung:9). It is an exclusive agreement between the creditor and debtor in order to give protection 
and legal assurance on the creditor's account receivable. The collateral agreement is made since the creditor and P2P lending administrator have less confidence to give credit to the debtor. Hence, there must be an emphasis as the benchmark of analysis valuation, and it is used as a guarantee just so the debtor pays the bill. Therefore, the criteria of collateral are stressed on the emphasis as one of the $5 \mathrm{C}$ principles that must be applied by the creditor and the administrator of P2P lending.

The principle of prudence is fundamental in providing credit. It is an in-dept analysis to get confidence in goodwill, capability and capacity of prospective debtor to pay his loans. In reaching this principle, both internal and external monitoring has been conducted. The purpose of this principle is that banks or lenders are always in good condition and run their businesses well and comply with legal provisions and norms that apply in the banking sector. Providing information about any potential risks that may happen in the agreement is a kind of prudence principle. In this case, it is relevant to the concept of the legal relationship between the engaged parties. It is not only between lender and borrower, but also about trust between them. Trust is very fundamental since they do not meet in person, but online.

Based on Article 8 along with the explanation of Act Number 10 Year 1998 about the Amendment of Act Number 7 Year 1992 about Banking, (Act Number 10 Year 1998 about Banking), banks are required to consider any terms and condition of providing credit, in addition to having trust to the debtor with good faith and capacity to pay his loans. Banks should consider any requirement and 5C principles. In this case, it stresses on collateral. As explained in the Decree of Director of Bank Indonesia No: 23/69/Kep/dir on 28 ${ }^{\text {th }}$ February 1991 about collateral, it mentions that the collateral gives confidence to banks for providing credit to the debtor, as they believe that the debtor is capable of paying his loans as what has been agreed to. It indicates that collateral agreement is an attempt to mitigate any potential risks that banks may encounter and give protection in the case the debtor turns into a defaulting debtor.

Prudence is set under Article 2 and Article 29 subsection (2) of Act Number 10 of 1998 about Banking, that includes: (1) secrecy principle, as set under Article 40, banks must keep into secret any informatifon about their customers along with their saving account; (2) know your customer principle: Banks should know their customers' identity, monitor their transactions including reporting any suspicious transactions.

The implementation of this prudence principle is the form of mitigating any potential risks as the part of risk management process which one of those is is the obligation to draw up a mitigation plan or risk response that aims to minimize any possible risks (Irham Wahyudi, 2019). The Standard of Risk Management, COSO Integrated Framework 2004 and ISO 310002009, mentions four strategies of risk mitigation that consist of avoiding, reduce, share, and accept. It stresses on the perspective of mitigating any possible risks during P2P lending agreement, 
preparing and anticipating any potential risks. Article 21 POJK 77/2016 has mentioned that both providers and users must mitigate any possible risk during their transactions. The essence of implementing risk mitigation is the sufficiency of risk management procedures just so the agreement remains under control on the acceptable limits, in addition to giving benefit among the engaged parties. every financial company must build a risk mitigation system that corresponds to each of its functions.

The implementation of fiduciary in Fintect P2P Lending is supervised by Financial Service Authority (i.e., OJK) that control any fintect acitivities. In this case, OJK has a special unit to control, supervise, certify, and anu other vital authorities on fintech industry. The literal domain of this unit is "Fintech Sertification and Supervision Unit", which particularly handles risk management on fintech business (Yuliyanti M Manan, 2019:78).

Mitigation of risks can also be applied through some ways, including a financing appraisal analysis. This analysis aims to select the prospective debtors that fit particular criteria. In addition, risk management team needs to review any business to be run by the debtors in order to see the feasibility of the business and to collect the debtor's collateral objects. For reducing the risks of bad credit, the creditors have some ways to cope with that problem by applying risk sharing, reconditioning the debtor's payment system, taking insurance on the debtor's business (if any) as well as collateral-based insurance, and taking buyback of the debtor's business in case of default on coaching and operational errors.

In terms of providing credit through financial technology service, some components should be taken into account, as follow:

Trust. The creditor should trust that the debtor has the capacity to pay the loans back as what they have agreed to through an application form the administrator has provided on their website in a particular period of time as mentioned in that agreement.

Time. There is a certain period of time between lending and disbursement. The application form contains some substances that one of which refers to a particular period of time for disbursement. Some creditors in fintech websites provide options of tenor from 7 (seven) up to 30 (thirty) days, and the debtor may choose one of the options to pay their loans. Those periods of time are made by the creditors and accepted by the debtor.

Performance. Particular objects in the form of performance and contraperformance when creditor and debtor have dealed to make credit agreement. It is in the form of money and interest. In credit agreement, performance occurs due to the object; money. In this case, the creditor performs by lending some amount of his money to the debtor. On the other hand, the debtor performs by paying back his loans along witih the interest as that has been previously agreed to. 
Risk. Risks may happen between the time of providing credit and the disbursement. The risk of credit agreement through P2P lending is huge as the engaged parties only get in touch though the online websites, not face-to-face. Both creditors and debtors are not families. Hence, the likelihood of default may potentially happen, on which the debtor fails to do his obligation to pay his loans along with interest, while acredit agreement through fintect service has no collateral binding.

The analysis carried out to provide credit in P2P lending tends to ignore the principles that conventional banks commonly apply. They analyze some aspects called 5C to get the most prospective customers who have the capacity to pay their loans. Those aspects are as follows (Niniek Wahyuni, 2017:15-16).

1) Character

The prospective customers should be absolutely trustworthy of having credit. It is apparent in their background, including their job and personal traits.

2) Capacity

To see that the customer has the capacity to control his business, which will be linked to his education background, his capacity to understand the governmental regulations, his capacity to lead and control his business, his persistence and visionary perspective just so his business run well and rendable that results in his capability to pay his loans.

3) Capital

It refers to the debtor's capital to develop his business. To see whether or not he effectively uses his business capital, it needs to see his financial report by taking the measurement on (for instance) his liquidity and solvency, rentability, and the other measures.

4) Collateral

It needs to consider any assets that can be taken as collateral in order to ensure that the debtor is capable of paying his loans. In this case, the collateral is not only in the form of the tangible object, but also intangible ones.

5) Condition of Economy

It refers to political, social, economic, and cultural conditions that may affect the economic condition during a particular period of time on which the bank provides credit to the applicant. It involves the applicant's business prospect that should be definitely excelent.

As common knowns that neither creditor nor administrator of the P2P lending agreement applies those $5 \mathrm{C}$ principles, especially in terms of collateral, given that the $\mathrm{P} 2 \mathrm{P}$ lending agreement is made online. The engaged parties do not need to meet in person. Thus, it is a kind of indirect caution about loan payment in case the debtor turns into default. Although there is confidence in payment without any collateral, it is still not considered safe for the creditor. Therefore, it needs to have collateral in the P2P Lending agreement. 
The default of payment may happen due to the administrator's inaccuracy in selecting, analyzing, and approving their customers' credit application to be proposed to the creditor. As a consequence, the administrator should be responsible for their creditor due to their less accurate appraisal. Article 37 POJK Number 77/POJK.01/2016 Information Technology-Based Credit Service mentions that the administrator should be responsible for any loss due to their negligence, board, and/or employees.

This article implies that the administrator should be responsible for their negligence selecting unqualified applicants which may lead to bad debtors, and the creditors are injured. Article 5 subsection (1) POJK Number 77/POJK.01/2016 Information Technology-Based Credit Service mentions that the administrator should take responsibility for not giving their best in managing and operating online-based credit services, and thus, it injures one of the engaged parties.

Furthermore, Article 27 subsection (1) POJK Number 77/POJK.01/2016 mentions that the administrator should provide their audit track record for entire fintech-based credit activities. This record is for supervision, dispute resolution, verification, legal assurance, testing, and the other examination. The security system conducted by fintech-based credit service administrators should consist of some procedures, preventing and overcoming any threats and onset that may put the users into default and injured. The administrator should participate in managing any security gap in information technology in the fintech industry. The administrator should take particular procedures and suggestions to protect their credit services so that they may prevent any default, nuisance, and loss among parties, especially those who use their fintech-based services (Kiestarina Marhenningsih, 2019:.69).

The administrator of fintech lending service aims to provide protection for their investors in the form of fund protection, which is actually against the regulation of collateral they have made. To prevent any default payment, Financial Service Authority (i.e., OJK) builds a system called Financial Information Service System (i.e., SLIK) for Fintech administrators to see their debtors' credit history. The collateral in P2P lending is fiduciary

Article 1 subsection (1) of Act Number 42/1999 mentions that the fiduciary is shifting the proprietary of an object based on trust and under a provision that the object which proprietary is shifted remains under the owner's governance. Hence, the terms of 'proprietary shift' is shifting the proprietary of the fiduciary object from the debtor to the creditor on the basis of trust, and with a provision that the collateral object remains on the debtor's hand. In addition, Article 1131 BW mentions that any movable and immovable assets that belong to the debtor, both existing and will exist, become his collateral objects in the credit agreement.

Fiduciary guarantee is a kind of collateral body and that the proprietary shift through constitutum possessorium is aimed to merely provide collateral which proprietary right belongs to the fiduciary recipient, and thus, every promise that gives authority to the fiduciary recipient to own the fiduciary object is null and 
void, as mentioned in Article 33 of Fiduciary Law. This regulation is established to protect particular fiduciary giver, in case that the value of the fiduciary object goes beyond the number of loans. Moreover, it is set under Article 32.

It is commonly known that the scheme of P2P lending agreement using the assessor agreement in the form of fiduciary agreement is inherent to the debtor (loan recipient), which governace remains on the debtor. In this case, it contains 2 (two) agreements, including the P2P Lending agreement as to the main agreement and the assessor/tail agreement in the form of a fiduciary guarantee. This agreement has a specific characteristic that the existence and termination of the collateral agreement -as an accessory agreement- are highly dependent on the main agreement (Hermansyah, 2008:71). In addition, the engaging agreement contains a clause in the form of right to take collateral as disbursement of the debtor's credit if he is unable to pay his debts to the bank or does not fulfill his performance (Sudaryat, 2008:74), and thus it results in a provision that on which the main agreement has ended, the assessor agreement will legally come to an end as well.

If we rely on an argument that fiduciary agreement is a kind of obligatory agreement, it only results in rights and obligations that can be sustained between them only, not for the third party. As a consequence, if the debtor turns into bankruptcy, the collateral objects in which proprietary shifting is under constitutum possessorium will be excluded from the bankruptcy, and the creditor will get the entire proprietary of those collateral objects in order to cover his account receivable.

Related to the selection of fiduciary guarantee institutions as a form of mitigation of P2P lending agreements because the parties also do not directly enter into such agreements face to face, but through the internet provided by the organizers. Therefore power is used as discussed in the previous chapter and the selection of fiduciary guarantee institutions is considered the most appropriate as a form of risk mitigation in P2P lending agreements. As mandated in Article 21 POJK Paragraph (1) POJK 29/2014, as stated by Efendi B. Peranginangin Kakanwil (Kemenkunham Kantor Wilayah Sulawesi Utara, 2019), Fiduciary Registration aims to protect creditors, because in the actual implementation of this fiduciary agreement the fiduciary object is located and controlled by the debtor. The existence of this fiduciary certificate becomes the basis and legal force for taking objects if the borrower is unable to repay the loan. Even the lender can get legal support from the legal apparatus as protection for the execution carried out (PT. Solusi Finansialku Indonesia, 2019).

In addition to providing the preferent right to fiduciary recipient, Fiduciary Law also contains some provisions that provide another protection for bank/ creditor against the third party. The provisions are as follows (Fatma Paparang, 2014:63).

1. Article 17: Fiduciary giver is not allowed to do re-fiduciary on the registered fiduciary object. This article urges the bank/creditor that receives a fiduciary 
object to register the fiduciary asset they have received immediately. It is important to conduct to give protection toward the bank/creditor and provide legal assurance for the third party with good faith.

2. Article 20: fiduciary guarantee remains following the fiduciary object on whoever's hand, but the proprietary shift of inventory that becomes a fiduciary object. This provision is based on droit de suite principle, and against Article 1977 BW. In addition, this article insists on making an accurate, trusted, accessible, and low-price registration system.

3. Article 22: the buyers of fiduciary objects which refer to inventory are free from any lawsuit although they know that it is the fiduciary object, under a condition that they have fully paid the sales price based on what applies in the marketplace. With this provision, the bank/creditor may sue the third party who buys the fiduciary object they receive under the market price, of course if the debtor is considered default which makes bank/creditor able to execute the fiduciary guarantee.

4. Article 23 (2): Fiduciary giver is not allowed to shift, pawn, or rent the fiduciary object (which is not classified into inventory) to another party, but under written consent from the fiduciary recipient at first. To protect his interest, the third party who accept shifting, lien, or rental rights over the fiduciary object should require a written agreement in the form of notariel from the fiduciary recipient.

5. Article 24: Fiduciary recipient will not carry on any obligation/responsibility due to any negligence by the fiduciary giver in a contractual relationship or due to any legal issue in relation to the utilization and shifting of the fiduciary object.

Basically, fiduciary on banks and fintech companies has a similar purpose as a legal protection for creditors in case of default by debtors in which they fail to repay their loans as mentioned in credit agreement. Therefore, the collateral of fiduciary will be executed for credit settlement. Although both banks and fintech companies have similar purposes on their function, the procedures are different between them. As we know, banks have privilege on their lexes, while fintech companies provide easy access to get fresh fund without any additional complicated procedures. However, both banks and fintech companies are supervised by OJK as Supervision Unit of Financial Organizations in Indonesia.

Toward the importance of collateral for the creditor (bank), it is an attempt to anticipate any possible risks that may happen in loan transactions ( $\mathrm{H}$. Budi Untung, 2000:57). With this fiduciary agreement, the creditor will be prioritized in credit disbursement when the debtor turns into bangkruptcy and thus they are not allowed to use their loans for another purpose. Furthermore, the fiduciary object will belong to the creditor if the debtor fails to do their performance set 
in the clause of the P2P lending agreement. The clause gives privilege to the creditor to become a preferent creditor.

Furthermore, in terms of providing credit through P2P lending services, some components should be taken into account, as follow:

(1) Trust. The creditor should trust that the debtor has the capacity to pay the loans back as what they have agreed to through an application form the administrator has provided on their website in a particular period of time as mentioned in that agreement.

(2) Time. There must be a certain period of time between lending and disbursement. The application form contains some substances that one of which refers to a particular period of time for disbursement.

(3) Performance. There is a particular object in the form of performance and contra-performance when creditors and debtors have dealed to make credit agreements. It is in the form of money and interest. In credit agreement, performance occurs due to the object (i.e., money). In this case, the creditor performs by lending some amount of his money to the debtor. On the other hand, the debtor performs by paying back his loans along witih the interest as that has been previously agreed to.

(4) Risk. Risks may happen between the time of lending and the disbursement. The risk of credit agreement through P2P lending is huge as the engaged parties only get in touch though the online website, not face-to-face. Both creditors and are not family. Hence, the likelihood of default may potentially happen, on which the debtor fails to do his obligation to pay his loans along with interest, while credit agreement through fintect service has no collateral binding.

\section{Conclusion}

The characteristics of credit agreement through P2P Lending is online-based, through which both creditors and debtors do not meet in person. Both offer and receipt are conducted through online in a provider's website. Although it does not require the engaged parties to meet in person, it is still a confining agreement for both parties. It begins by getting the prospective debtors to provide any required documents as the credit prerequisite by the creditors. This service gives an easy access on its procedures for debtors.

The implementation of collateral as the principle of prudence/circumspection in peer-to-peer lending services aims as a legal protection and risk mitigation for creditors. One preferent collateral is fiduciary, as it allows the debtors to remain using the collateral object although the proprietary right of the object has been shifted to the creditors. In case of default by debtors, the creditors enables to mitigate any huge loss by proposing an appeal to execute the collateral object based on the proprietary right of certificate they have. As creditors with fiduciary assurance, they become a preferent creditor who has a privilege right to get their money back. 


\section{BIBLIOGRAPHY:}

\section{Books with an author:}

Gatot SupramoNumber (2009). Perbankan dan Masalah Kredit: Suatu Tinjauan di Bidang Yuridis. Jakarta: Rineka Cipta.

Hermansyah. (2008). Hukum Perbankan Indonesia. Jakarta: Kencana Prenada Media Group.

Prajitno, A.A. Andi. (2009). Hukum Fidusia : Problematika Yuridis Pemberlakuan UndangUndang Number 42 Tahun 1999. Malang: Bayumedia.

Sudaryat. (2008). Hukum Bisnis Suatu Pengantar. Bandung: Jendela Mas Pustaka.

Untung, H. Budi. (2005). Kredit Perbankan Di Indonesia. Yogyakarta: Andi Yogyakarta.

Journals:

Alficha Rezita Sari. (2018). "Perlindungan Hukum Bagi Pemberi Pinjaman Dalam Penyelenggaraan Financial Technology Berbasis Peer To Peer Lending Di Indonesia", Skrispsi Fakultas Hukum Universitas Islam Indonesia.

Darman. (2019). “Financial Technology (FinTech): Karakteristik dan Kualitas Pinjaman pada Peer to Peer Lending di Indonesia", Jurnal Manajemen Teknologi. Vol. 18. Number 2.

Etty Mulyati, Fajrina Aprilianti Dwiputri. (2018). "Prinsip Kehati-hatian Dalam Menganalisis Jaminan KebendaanSebagai Pengaman Perjanjian KreditPerbankan", Acta Diurnal - Jurnal Hukum Kenotariatan dan ke PPAT an. Vol. 1. Number 2.

Fatma Paparang. (2014). "Implementasi Jaminan Fidusia Dalam Pemberian Kredit Di Indonesia”, Jurnal LPPM Bidang EkoSosBudKum. Vol. 1. Number 2.

Kiestarina Marhenningsih. (2019). "Karakteristik Perjanjian Kredit Tanpa i..Agunan Melalui Layanan Teknologi Finansial", Skripsi Universitas Hang Tuah.

Moch Najib Imanullah. (2018). “Equalizing The Bank Position And Businesses In Credit Agreement With The Guarantee Of Mortgage", Yustisia. Vol.7. Number 1.

Niniek Wahyuni. (2017). "Penerapan Prinsip 5C Dalam Pemberian Kredit Sebagai Perlindungan Bank", Jurnal Hukum Fakultas Hukum Universitas Kediri. Vol. 1. Number 1.

Paul Belleflamme et, al. (2015). "The Economics of Crowdfunding, Centre for Operation Research and Econometrics".

Riedel Wawointana. (2013). “Manfaat Jaminan Fidusia Dalam Pelaksanaan Perjanjian Kredit Bank", Lex Privatum. Vol.1. Number 3.

Pranoto, P., Kholil, M., \& Tejomurti, K. (2019). FINTECH LENDING: CHALLENGE AND OPPORTUNITIES OF THE INDONESIA'S LOAN UNBANKED TO DEVELOP THE INCLUSIVE FINANCIAL INDUSTRY. Hang Tuah Law Journal, 3(2), 105-119

114 Yustisia Volume 9 Number 1 (January-April 2020)

The Existence of Collateral in Credit... 
Priskarini, I. A., \& Tejomurti, K. (2019). The Role of The Financial Services Authority in The Legal Protection of Privacy Rights in Connection with Personal Data of Fintech Lending Debtor in Indonesia. Padjadjaran Journal of Law, 6(3), 556-575

Trisadini Prasastinah Usanti., et al. (2019). “The Legal Principle Of Collateral In Fintech Lending", Hang Tuah Law Journal. Vol. 3. Issue 2.

Wahyu Hanggoro SuseNumber (2008). “Kontrak Perdagangan Melalui Internet Ditinjau Dari Hukum Perjanjian", Skripsi Fakultas Hukum Universitas Sebelas Maret.

Yuliyanti M Manan. (2019). “Sistem Integrasi Proteksi \& Manajemen Resiko Platform Fintech peer to peer (P2P) Lending dan Payment Gateway untuk Meningkatkan Akselerasi Pertumbuhan UMKM 3.0", Journal of Islamic Economics, Finance, and Banking, Vol. 2. Number 1.

\section{Websites:}

Irham Wahyudi, Strategi Mitigasi Risiko, www.apb-group.com/strategi-mitigasi-risiko-1/ accessed on $9^{\text {th }}$ September 2019.

Kemenkunham Kantor Wilayah Sulawesi Utara, Mitigasi Risiko Pembiayaan Melalui Jaminan Fidusia, https://sulut.kemenkumham.go.id/berita-kanwil/berita-utama/2700sosialisasi-layanan-fidusia, accessed on $3^{\text {rd }}$ October 2019.

PT. Solusi Finansialku Indonesia, Definisi Fidusia, https://www.finansialku.com/fidusiaadalah/, accessed on $18^{\text {th }}$ September 2019. 